\title{
Grain size distribution of aggregates of crushed concrete
}

\author{
Natalya Fomina* and Mikhail Polyanskiy \\ Yuri Gagarin State Technical University of Saratov, Department Building Materials and \\ Technologies", Polytechnic St., 77, Saratov, Russia
}

\begin{abstract}
The results of studies of recycling aggregates obtained by crushing concrete scrap are presented. The heterogeneity of the material received as a result of crushing concrete scrap, complicates the task of selecting the fractional composition of aggregates. The presence of the mortar component in recycled aggregates significantly increases their water demand. This indicates the expediency of their use in a mixture with natural ones. This work aimed at optimizing the granulometry of recycling rubble and sand. Concrete scrap was used for the research. It was represented by destroyed samples of heavy concrete cubes. Standard methods for determining the grain composition and properties of aggregates of concrete, manufacturing and testing mortar mixes were used. It has been shown that recycling rubble of the $5-20 \mathrm{~mm}$ fraction has a minimum voidness when it contains $35 \%$ of the $5-10 \mathrm{~mm}$ grains and $65 \%$ of the $10-20 \mathrm{~mm}$ grains, which is close to the ratio of these fractions in the initial crushing product. Therefore, it is advisable to use recycling rubble fractions of 5-20 mm without separation into fractions. The rather high content in the recycling sand of grains with a particle size of more than $0.63 \mathrm{~mm}$ indicates the feasibility of using it in a mixture with natural fine and very fine sand. A grain-optimized mixture of natural very fine sand ( $46 \%$ of the total mass of mixed sand) and coarse fractions $(0.63-5 \mathrm{~mm})$ of recycled sand $(54 \%)$ is proposed. Should be considered that recycled sand has increased water demand.
\end{abstract}

\section{Introduction}

During the reconstruction of buildings, demolition of old constructions a large amount of construction waste is generated. Mostly this waste is represented by concrete scrap (approximately 50-55\%) and brickwork (30-40\%) [1]. The volume of construction waste generation is very impressive. Annually about 14 million tons generate in the Netherlands, 20 million tons in the UK, 200 million tons in China, up to 17 million tons in Russia [1-3]. The easiest way to dispose construction waste is their crushing and use in road construction as a material for bedding. It is possible that a more effective direction for the utilization of concrete scrap is to return it into production of concrete and reinforced concrete structures. Products crushing concrete scrap can act as active or inert components of cement composites, because they have an affinity for the cement matrix. The experience of processing concrete scrap into "new" concrete accumulated in Germany, the United States

\footnotetext{
* Corresponding author: fominanani@yandex.ru
} 
and the Netherlands showed $[4,5]$ that the cost of "new" concrete on crushed stone from concrete scrap is significantly lower than with traditional aggregates.

Recycling aggregates (gravel and sand) and fine fraction (filler) form during crushing concrete. The grain composition of the material resulting from crushing concrete scrap, presented in a number of works (Table 1), shows that regardless of the type of crushing and grinding equipment and the strength of the original concrete, the yield of recycled gravel is over $76 \%$.

Table 1. The Composition of the material resulting from the crushing of concrete scrap.

\begin{tabular}{|c|c|c|c|c|}
\hline \multirow{4}{*}{ Components } & \multicolumn{4}{|c|}{ Content,\% of the total mass, according to } \\
\cline { 2 - 5 } & {$[6,7]$} & {$[8]$} & {$[9, \mathrm{p} .71]$} & {$[5$, Figure 3] } \\
\cline { 2 - 5 } & \multicolumn{4}{|c|}{ Crushing equipment } \\
\cline { 2 - 5 } & $\begin{array}{c}\text { crushing and sorting } \\
\text { complex EXTES }\end{array}$ & $\begin{array}{c}\text { laboratory jaw } \\
\text { crusher ЩД-6 }\end{array}$ & $\begin{array}{c}\text { primary crushing } \\
\text { plant УПН-7 }\end{array}$ & jaw crusher \\
\hline \multirow{2}{*}{ rubble } & $76.7-80.9$ & 76.1 & $77.9-84.0$ & $77.0-78.0$ \\
\hline \multirow{2}{*}{ sand } & $13.9-18.2$ & 19.7 & $16.0-22.1$ & $22.0-23.0$ \\
\hline filler & $4.2-5.8$ & 4.2 & & \\
\hline
\end{tabular}

Analysis of the grain composition of sand and fine fractions obtained by crushing concrete scrap, according to a number of studies (Table 2), can vary widely. This is obviously determined by the type of equipment used for crushing, the technological regimes of crushing and the initial properties of the processed concrete scrap. It is possible to obtain recycled sands of class II of increased particle size [10] and large ones [8, 11] according to GOST 8736 , with a small (up to $5-13 \%$ by weight) content of the fine fraction. The opposite is also possible. I could be obtained a mixture of sand fraction with a large amount (up to $45 \%$ ) of the fine fraction $[12,10]$. Moreover, this mixture is not recommended as construction sand. All this indicates the possibility of obtaining a given granulometry of aggregates and fillers in the recycling of concrete scrap.

Some of the quality characteristics of recycled rubble are presented in Table 3 . With increasing grain size, the strength increases. It is explained by the presence in the fraction of 5-10 mm more cement stone than in the fraction of 10-20 mm, represented, in its main mass by the primary rubble. The surface roughness and increased surface porosity cause higher water absorption values of recycled rubble in comparison with natural, according to most researchers. However, there is also different information [13].

As for the water resistance of recycled rubble the experimental data are different. The author [13] indicates a sharp decrease in the strength of recycling rubble at water saturation. Our earlier studies [8] indicate a slight change in strength at water saturation. 
Table 2. Grain composition of sand and fine fractions resulting from crushing of concrete scrap.

\begin{tabular}{|c|c|c|c|c|c|c|}
\hline \multirow{5}{*}{$\begin{array}{l}\text { Partial } \\
\text { sieve } \\
\text { residue } \\
\text { with mesh } \\
\text { size, mm }\end{array}$} & \multicolumn{6}{|c|}{ Type of material resulting from crushing concrete scrap } \\
\hline & \multicolumn{3}{|c|}{$\begin{array}{l}\text { screenings of crushing concrete } \\
\text { scrap of crushing and sorting plant } \\
\text { of "Satori" LLC, Moscow }\end{array}$} & $\begin{array}{l}\text { screening of } \\
\text { concrete crushing } \\
\text { according to } \\
\text { Japanese experts }\end{array}$ & \multicolumn{2}{|c|}{$\begin{array}{c}\text { laboratory samples } \\
\text { crushing concrete scrap, } \\
\text { after sifting through a } \\
\text { sieve with a mesh size of } \\
5 \mathrm{~mm}\end{array}$} \\
\hline & \multicolumn{6}{|c|}{ Content, $\%$ of the total mass, according to } \\
\hline & \multirow{2}{*}{ [12] } & \multicolumn{2}{|c|}{ [10] } & \multirow{2}{*}[9,\text{Table}18]{} & \multirow{2}{*}{ [11] } & \multirow{2}{*}{ [8] } \\
\hline & & Sample 1 & Sample 2 & & & \\
\hline 5 & 18 & 18 & 20 & - & - & - \\
\hline 2.5 & 10 & 10 & 40 & $0-10$ & 22 & 25 \\
\hline 1.25 & 9 & 7 & 15 & $10-30$ & 12 & 25 \\
\hline 0.63 & 8 & 10 & 12 & $15-25$ & 16 & 12 \\
\hline 0.315 & 6 & 5 & 7 & $10-35$ & 31 & 15 \\
\hline 0.16 & 5 & 5 & 1 & $5-10$ & 8 & 10 \\
\hline pallet & 44 & 45 & 5 & $0-20$ & 11 & 13 \\
\hline
\end{tabular}

Table 3. Recycled rubble properties.

\begin{tabular}{|l|c|c|c|c|c|c|c|c|}
\hline \multirow{2}{*}{ Properties } & \multicolumn{7}{|c|}{ Values, according to } \\
\cline { 2 - 9 } & \multicolumn{2}{|c|}{$[8]$} & \multicolumn{2}{|c|}{$[6,14]$} & $\begin{array}{c}{[9,} \\
{[15]}\end{array}$ & $\begin{array}{c}\text { Table } \\
16-17]\end{array}$ & {$[16]$} & {$[13]$} \\
\hline Fraction, mm & $10-20$ & $5-10$ & $10-20$ & $5-10$ & $5-20$ & $5-20$ & $5-10$ & $5-40$ \\
\hline $\begin{array}{l}\text { Crushability, \%, } \\
\text { (mark by } \\
\text { strength), in the } \\
\text { dry state }\end{array}$ & $\begin{array}{c}14.0 \\
(800)\end{array}$ & $\begin{array}{c}20.8 \\
(400)\end{array}$ & $(400)$ & $(300)$ & $(400)$ & $\begin{array}{c}24.0 \\
(400)\end{array}$ & $\begin{array}{c}26.0 \\
(400)\end{array}$ & $\begin{array}{c}21.0 \\
(400)\end{array}$ \\
\hline $\begin{array}{l}\text { The same, in the } \\
\text { water saturated } \\
\text { state }\end{array}$ & $\begin{array}{c}14.5 \\
(800)\end{array}$ & $\begin{array}{c}21.7 \\
(400)\end{array}$ & - & - & - & - & - & $\begin{array}{c}26.0 \\
(200)\end{array}$ \\
\hline $\begin{array}{l}\text { Water absorption, } \\
\%\end{array}$ & \multicolumn{2}{|c|}{$7.5-8.0$} & - & - & - & 7.0 & 7.5 & 2.55 \\
\hline
\end{tabular}


There are remain problematic issues in research of using recycled concrete despite the accumulated experience of using recycling aggregates in cement composites and a fairly wide amount of research in this direction. The heterogeneity of the material received as a result of crushing concrete scrap, complicates the task of selecting the fractional composition of aggregates. The presence of the mortar component in recycling aggregates significantly increases their water demand, which indicates the expediency of their use in a mixture with natural ones.

This work aimed at optimization the granulometry of recycled rubble and sand.

\section{Materials and Methods}

Concrete scrap produced in the laboratory for testing and research of construction products, represented by destroyed samples of heavy concrete cubes, was crushed on a laboratory jaw crusher ЩД-6. The fractional composition of the material resulting from crushing was determined by sieving through standard sets of sieves. Grain composition, crushability, average and bulk density, emptiness of recycling rubble were determined according to GOST 8269.0. The strength of recycled rubble, depending on the crushability, was evaluated according to GOST 35495, GOST 8267. Grain composition, size modulus, true density of recycled and natural sands were determined according to GOST 8735 . The water-cement ratio of cement-sand mortars using recycling and natural sands, also their mixtures, was established by the method of GOST 310.4. Portland cement CEM I 42.5 R was used as a binder.

\section{Results and Discussion}

According to GOST 26633, the optimum ratio between aggregate fractions in a mixture of fractions $5-20 \mathrm{~mm}$ - between $25-40 \%$ of a fraction $5-10 \mathrm{~mm}$ should account for $60-75 \%$ of a fraction 10-20 mm. The ratio between the fractions is determined experimentally and should provide minimal aggregate voidness.

The emptiness of recycling rubble fractions 5-10 $\mathrm{mm}$ and $10-20 \mathrm{~mm}$, and their mixtures are presented in Table 4.

Table 4. Voidness of recycled rubble mixtures of fractions.

\begin{tabular}{|c|c|c|c|}
\hline \multicolumn{2}{|c|}{$\begin{array}{c}\text { The amount of fraction, \% of the total mass of the mixture } \\
\text { fractions }\end{array}$} & $\begin{array}{c}\text { Bulk density, } \\
\mathbf{~ k g} / \mathbf{m}^{3}\end{array}$ & Voidness,\% \\
\hline $5-10$ & $10-20$ & 990 & 54 \\
\hline 0 & 100 & 1170 & 46 \\
\hline 100 & 0 & 1160 & 48 \\
\hline 35 & 75 & 1260 & 43 \\
\hline 40 & 65 & 1200 & 46 \\
\hline
\end{tabular}

It has been established that the mixture of fractions containing $35 \%$ of grains of $5-10$ $\mathrm{mm}$ and $65 \%$ of grains of $10-20 \mathrm{~mm}$ fraction has the minimum voidness. This ratio is very 
close to the ratio of these fractions in the initial crushing product (37\% of the fraction $5-10$ $\mathrm{mm} ; 63 \%$ of the grains of the fraction $10-20 \mathrm{~mm}$ ). Therefore, it is advisable to use recycling rubble fractions of 5-20 $\mathrm{mm}$ without splitting it into fractions. This is confirmed by studies [15], which also use a mixture of 5-20 mm recycled rubble fractions, having a bulk density of $1310 \mathrm{~kg} / \mathrm{m}^{3}$ and a hollowness of $38 \%$. A close ratio of recycled rubble fractions [7] uses $29 \%$ of the fraction $5-10 \mathrm{~mm}$ and $71 \%$ of the fraction $10-20 \mathrm{~mm}$ (i.e. in a 1: 2.5 ratio). Gusev [9] indicates the ratio - to $33 \%$ of the $5-10 \mathrm{~mm}$ fraction $67 \%$ of the $10-20 \mathrm{~mm}$ fraction (i.e. in the 1:2 ratio), noting the possibility of directly using the 5-20 mm fraction with a bulk density of $1170 \mathrm{~kg} / \mathrm{m}^{3}$, separated from the total mass of the crushing product, as a filler [9].

Optimization of sand granulometry was as follows. Previously obtained results [8] show a rather large content in the recycled sand grains with a particle size of more than $0.63 \mathrm{~mm}$ (total residue 62\%). Therefore, it is advisable to use this sand in a mixture with natural very fine sands.

The grain composition of the sands is presented in table 5. The recycling sand sieving curve (Fig. 1) is in the area of "ideal" curves. This corresponds to the most dense packaging of a mixture of grains. But the complete replacement of natural quartz sand with recycling sand will lead to an increase in the water content of concrete mixes due to the increased water demand of recycled aggregates. Mixing of natural and recycled sands in different ratios, as shown by experimental data (Table 5, Fig. 1), does not significantly improve the grain size distribution of natural sand. It should be noted that for such a preliminary experiment we have adopted a significant simplification. Natural quartz and recycled sands has a different density in the grain $\left(2.63 \mathrm{~g} / \mathrm{cm}^{3}\right.$ for natural and $2.15 \mathrm{~g} / \mathrm{cm}^{3}$ for recycling). So volumetric optimization methods would be more accurate.

Due to the apparent excess of fine fractions in natural and mixed sands and due to the high water demand for recycled sand, it was decided to weed out small fractions from recycled sand. Then only coarse fractions (more than $0.63 \mathrm{~mm}$ ) of recycled sand used to enrich natural sand. The theoretical grain composition of mixed sand was calculated based on two conditions:

1) the mixture should contain the maximum possible amount of natural sand;

2) the grain composition of mixed sand should correspond to the area of sands of optimal granulometry.

The calculation obtained that mixed sand should contain $46 \%$ of natural sand and $54 \%$ of large fractions of recycled sand (Table 5, Fig. 2). Experimental verification of the grain composition of the calculated mixture showed the adequacy of the results. The discrepancy between the calculated and experimental grain compositions of mixed sand (in the estimated composition of more large fractions) is due to the fact that when mixed, there is a partial grinding of large fractions of recycled sand.

The water demand of mortar mixes containing recycled sand (Table 5) was investigated. The obtained data on the higher water demand of recycled materials compared to natural ones are consistent with many studies $[3,5,15,17]$. It was shown [6-7] that with increasing grain size of recycled sand its water absorption increases: from $1.7 \%$ for the $0.16-0.315 \mathrm{~mm}$ fraction to $5-6 \%$ for the $2.5-5 \mathrm{~mm}$ fraction. The authors explain this by the presence of porosity in large grains and the absence of it in small particles. The water-cement ratio in cement-sand solutions of fixed mobility increases from 0.48 in solutions on natural sand with $\mathrm{Mk}=2.62$ to 0.5 in solutions on recycled sand [6]. 
Table 5. The grain composition of the sands.

\begin{tabular}{|c|c|c|c|c|c|c|c|}
\hline \multirow{2}{*}{ Sand } & \multicolumn{5}{|c|}{ Total residues, \% } & \\
\cline { 3 - 7 } & & 2.5 & 1.25 & 0.63 & 0.315 & 0.14 & $\begin{array}{c}\text { Water-cement ratio in } \\
\text { mortar compositions } \\
\text { "cement : sand = 1 : 3" }\end{array}$ \\
\hline 1 & Natural & 0 & 1 & 2 & 24 & 97 & 0.5 \\
\hline 2 & Recycled & 22 & 47 & 60 & 79 & 88 & 0.75 \\
\hline
\end{tabular}

A mixture of natural and recycled sand in a ratio, $\%$ by weight

\begin{tabular}{|c|c|c|c|c|c|c|c|}
\hline 3 & $90: 10$ & 3 & 5 & 7 & 30 & 96 & 0.5 \\
\hline 4 & $70: 30$ & 9 & 15 & 17 & 36 & 95 & 0.6 \\
\hline 5 & $50: 50$ & 17 & 27 & 31 & 50 & 97 & 0.65 \\
\hline 6 & $20: 80$ & 20 & 40 & 51 & 68 & 97 & 0.68 \\
\hline 7 & $\begin{array}{c}\text { Recycled sand } \\
\text { without fine } \\
\text { fractions }\end{array}$ & 37 & 77 & 100 & 100 & 100 & 0.95 \\
\hline
\end{tabular}

A mixture of natural and recycled without fine fractions sand in a ratio, \% by weight

\begin{tabular}{|c|c|c|c|c|c|c|c|}
\hline 8 & $\begin{array}{c}46: 54 \\
\text { (calculated) }\end{array}$ & 20 & 42 & 55 & 65 & 99 & - \\
\hline 9 & $\begin{array}{c}46: 54 \\
\text { (experimental) }\end{array}$ & 13 & 42 & 61 & 68 & 96 & 0.6 \\
\hline
\end{tabular}

Our experimental data obtained on solutions with very fine natural sand $(\mathrm{Mk}=1.2)$ and recycled sand showed the following. Water-cement ratio at fixed mobility increases with increasing concentration of recycled sand: from 0.5 (in solutions without recycled sand) to 0.75 (in solutions without natural sand). Water demand rises sharply and there is no coherence after screening out fine fractions of recycled sand in the mortar mix on fully recycled sand. The water requirement of the solution corresponds to $\mathrm{W} / \mathrm{C}=0.6$ (Table 5) with the mixed sand of optimal granulometry ( $46 \%$ of natural very fine sand and $54 \%$ of large fractions of recycled sand). 


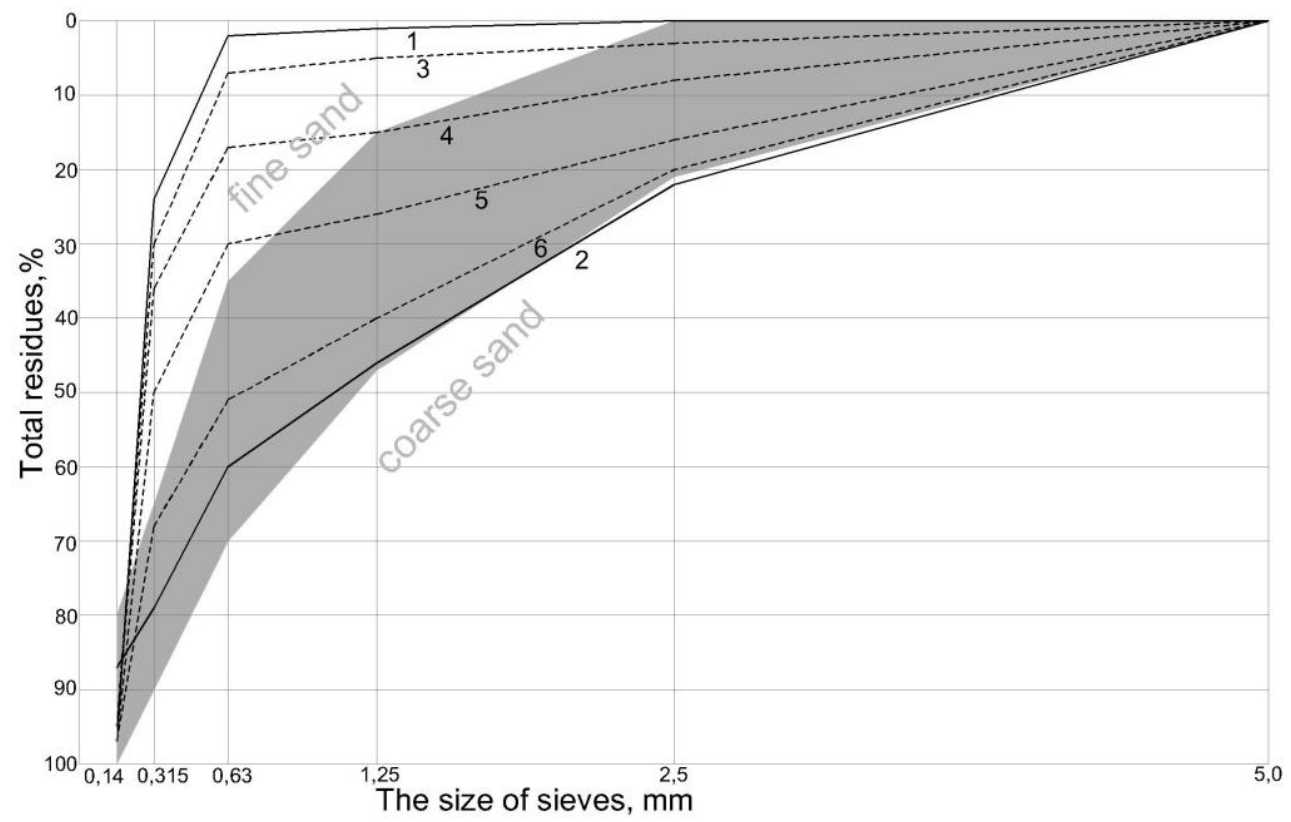

Fig.1. Sand sifting curves natural and recycled sand (position 1-6 at the Table 5).

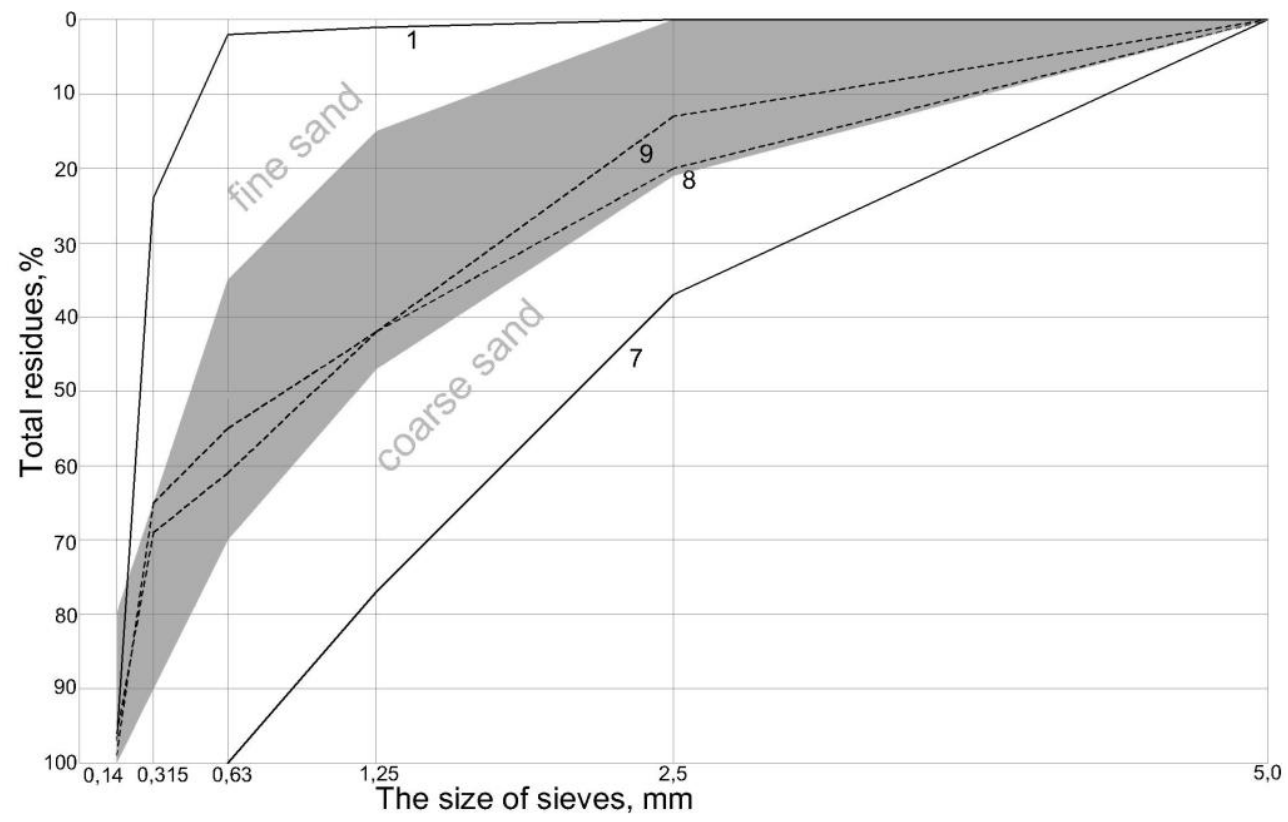

Fig.2. Sand Sifting Curves natural and recycled without fine fractions sand (position 1, 7-9 at the Table 5). 


\section{Conclusions}

The conducted studies allow us to draw the following conclusions.

Recycled rubble of a fraction of 5-20 $\mathrm{mm}$ has a minimum voidness when it contains $35 \%$ of grains of a fraction of $5-10 \mathrm{~mm}$ and $65 \%$ of grains of a fraction of $10-20 \mathrm{~mm}$. This is close to the ratio of these fractions in the original crushing product. It is advisable to use recycling rubble fractions of 5-20 $\mathrm{mm}$ without separation into fractions.

The rather high content in the recycled sand of grains with a particle size of more than $0.63 \mathrm{~mm}$ indicates the feasibility of using it in a mixture with natural fine and very fine sand. Mixed sand, optimized for grain size and water demand, contains $46 \%$ by weight of natural very fine sand and $54 \%$ of large fractions $(0.63-5 \mathrm{~mm})$ of recycled sand.

\section{References}

1. K. H. Khayat, S. Sadati. Recycled Concrete Aggregate: Field Implementation at the Stan Musial Veterans Memorial Bridge, 180 (Washington, 2014)

2. V. A. Arsentev, V. Z. Marmande, D. D. Dobromyslov. Stroitelnye materialy, 8, 64-66 (2006)

3. V. I. Kalashnikov. Ehffektivnye vysokoprochnye i obychnye betony, 148 (Penza, 2015)

4. P. P. Olejnik. Organizaciya sistemy pererabotki stroitel'nyh othodov i poluchenie vtorichnyh resursov, 193 (Saratov, Vuzovskoe obrazovanie, 2013)

5. M. V. A. Florea, H. J. H. Brouwers. Cement and Concrete Research, 53, 11, 278 (2013)

6. P. N. Kurochka, R. R. Mirzaliev. Inzenernyj vestnik Dona, 4, 2 (2012)

7. R. R. Mirzaliev. Betony s zapolnitelyami iz produktov drobleniya vtorichnogo betona. Abstract PhD dissertation, 24 (Rostov-on-Don, 2013)

8. M. M. Polyanskij, N. N. Fomina, T. V. Akopyan. Sustainable development of the region: architecture, construction, transport: IV International scientific and practical conference, 286-289 (Tambov, 2017)

9. B. V. Gusev, V. A. Zagurskij. Vtorichnoe ispolzovanie betonov, 98 (Moscow, Strojizdat, 1988)

10. A. S. Pilipenko. Ehffektivnye dekorativnye fasadnye betonnye izdeliya s ispol'zovaniem otsevov drobleniya betonnogo loma. Abstract PhD dissertation, 22 (Moscow, 2012.)

11. A. S. Uspanova. Stroitel'nye shtukaturnye rastvory na nekondicionnyh melkih peskah $i$ tekhnogennom syr'e. Abstract PhD dissertation, 24 (Makhachkala, 2012)

12. M. V. Krasnov. Ehffektivnyj neavtoklavnyi penobeton $s$ ispol'zovaniem otsevov drobleniya betonnogo loma. Abstract PhD dissertation, 23 (Moscow, 2009)

13. I. I. Romanenko, M. I. Romanenko, I. N. Petrovnina, Eh. M. Pint, K. A. Elichev. Naukovedenie, 7, 1 (2015)

14. P. N. Kurochka, R. R. Mirzaliev. New Technologies, 2, 104-109 (2013)

15. S. M. Pulyaev. Betony na zapolnitelyah iz betonnogo loma dlya sbornyh zhelezobetonnyh izdelij. Abstract PhD dissertation, 20 (Moscow, 2005)

16. M. O. Korovkin, A. I. Shesternin, N. A. Eroshkina. Inzenernyj vestnik Dona, 3 (2015)

17. M. O. Korovkin, N. A. Eroshkina, A. I. Shesternin, A. A. Urazova. Obrazovanie i nauka v sovremennom mire. Innovacii, 6-2, 226-234 (2016) 